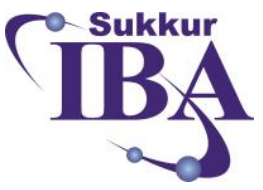

Volume: 3, No. 1 | April 2016

Sukkur IBA

TOURAL OF

Management

JBUSINESS

sijmb.iba-suk.edu.pk

\title{
Does Diversification towards Oilseeds Production reduce the Import burden in Pakistan?
}

\author{
Asif Ali Abro*1 \\ Ph.D Scholar at \\ Department of Economics, University of Karachi, Pakistan \\ Zeeshan Atique ${ }^{2}$ \\ Assistant Professor at \\ Department of Economics, University of Karachi, Pakistan
}

Iqbal Ahmed Panhwar

Professor of Management Sciences

Bahria University, Karachi, Pakistan

\begin{abstract}
Agriculture, constitutes a large segment of Pakistan's economy, is facing problems in the production of oilseed crops. The situation is getting bad to worse due to increase in population and demand of oilseeds has increased from 1.298 million tons to 3.069 million tons during the last thirty three years with the same local production capacity. During 2013-14, the local oilseed production comprised of 17.9 percent of the total consumption, while the remaining 82.1 percent of the demand was fulfilled through import. The Ordinary Least Square (OLS) technique is applied to examine the impact of different factors on the IHVC in Pakistan. The regression coefficient of import of oilseeds showed a negative and highly significant impact which indicated that huge import of oilseeds badly affects the public exchequer. The regression coefficient of number of tube wells, availability of credit and farm machinery (tractor) showed a positive and significant impact on IHVC. The regression coefficient of local production of oilseed crops showed a positive and significant impact, it showed that increasing the area for production of oilseeds enhanced the contribution of high value crops in GDP resultantly reduce the import burden.
\end{abstract}

Key words: Index of High Value crops, Crop Diversification, Oilseeds, Yield potential, yield gap

https://doi.org/10.30537/sijmb.v3i1.134

* Corresponding Author

1 aliasifabro15@gmail.com

2 zatique@uok.edu.pk

3 Iqbalahmed14@ hotmail.com

SIJMB | E-ISSN: 2410-1885; P-ISSN: 2313-1217 @ 20161 Sukkur Institute of Business Administration - All rights reserved 


\section{Introduction}

Agriculture sector is an important sector of the Pakistan's economy, is facing problems in the production of oilseed crops. The local oil seed production comprised of 17.9 percent of the total domestic consumption, while the remaining huge shortage of 82.1 percent of consumption was fulfilled through imports, during 2013-14 (Economic Survey of Pakistan 2014-15). Due to decline in local production of oilseed crops, the import is growing rapidly every year and causing the huge expenditure on account of it. Farmers are less concerned to increase the area and production of oilseed crops on the grounds that growing season of oilseed crops coincides to growing season of wheat and they are not interested to give up their main crop. The oilseed crops are required to be promoted among farmers by ensuring excellent return in market, resulting, the local production of the oilseeds crops will enhance to meet the requirement of the huge growing population.

The trends show a slow pattern of crop diversification in crop sector in terms of grains, cash crops, pulses, oilseeds, vegetables, fruits and other minor crops from 1980 to 2013. The area share of food grains (wheat, rice, bajra, Jowar, maize and barley) was 56 percent of the total cropped area during the year 1980 and it remained 56 percent of the total cropped area during 2012-13 having nil percent increase in cropped area during the last three decade. Furthermore, the contribution of cash crops during the year 1980 was 15 percent and increased up to 19 percent in 2012 showing the growth of 4 percent. Pulses, oilseeds, vegetables, fruits and other minor crops contributed 5 percent, 3 percent, 2 percent, 4 percent and 12 percent respectively to the total cropped area during the year 2012. Area share of oilseeds and vegetables remained same from 1980 to 2012, only area share under fruit cultivation showed a small increase of 2 percent while pulses recorded decline by 1 percent during the last thirty three years under study (Agricultural Statistics of Pakistan, 1980-81 to 2013-14).

Pakistan is facing acute shortage of edible oil production, about 82.1 percent of the total demand was imported and only 17.9 percent of edible oil need was met through domestic production. The status of domestic production, import and total consumption of edible oil in Pakistan is provided at annexure-A. It showed that domestic production of edible oil during the year 1980 was 247 thousand tons while 465 thousand tons of edible oil was imported which was 65.3 percent of the total availability during the same year. The current deficiency was observed during the years 2007, 2008, 2012 and 2013, and domestic production of edible oil was recorded 588 thousand tons, 565 thousand tons, 567 thousand tons and 573 thousand tons respectively. The import during the same periods were 2700 thousand tons, 2489 thousand tons, 2502 thousand tons and 2,627 thousand tons which were 82.1 percent, 81.5 percent, 81.5 percent and 82.1 respectively of the total availability of edible oil in Pakistan (Agricultural Statistics of Pakistan, 1980-81 to 2013-14).

Figure-1 showed that local production of oilseed crops failed to meet the consumption needs of the peoples of Pakistan and therefore the domestic production line and import

SIJMB | P-ISSN: 2313-1217 E-ISSN: 2410-1885 @ 20162 Sukkur Institute of Business Administration V.3, No.1 | Apr 16 
of oilseeds line were started separating from each other and the gap between the two lines were increasing with the passage of time.

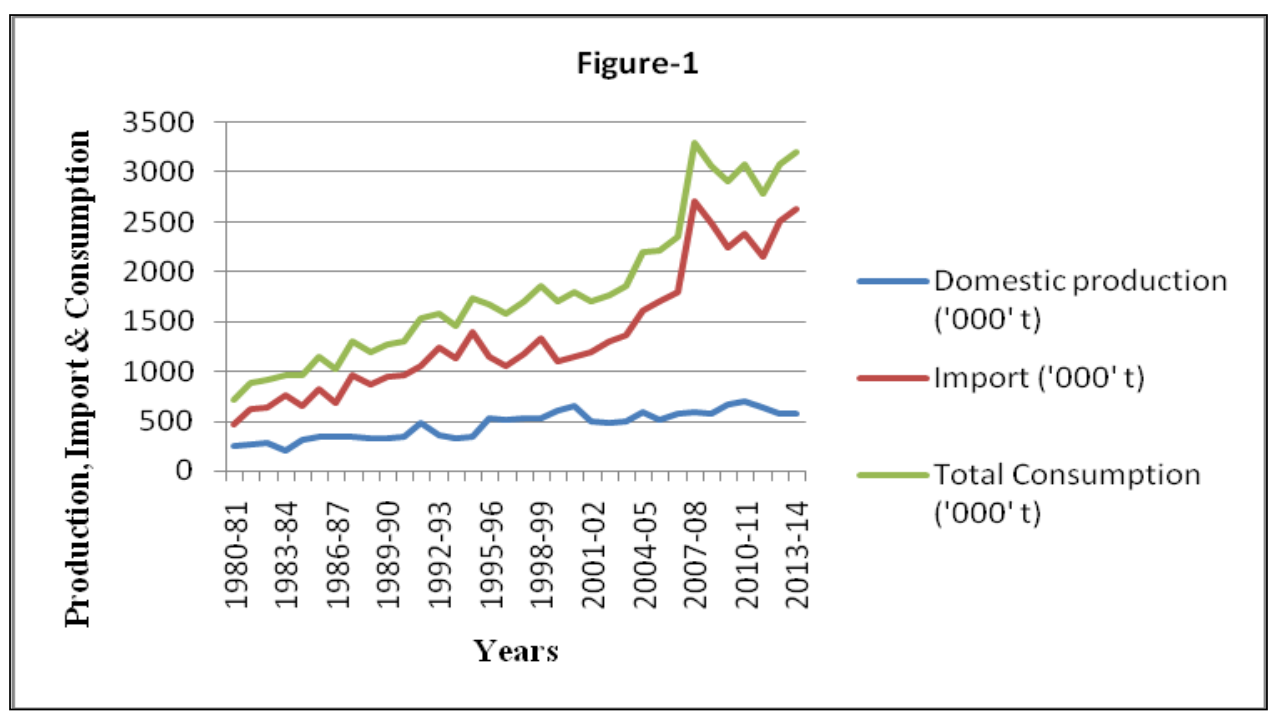

Due to import of edible oil, the expenditure on this account was growing rapidly from Rs.2.61 billion to Rs.246.89 billion from 1980 to 2013 which cost the public exchequer badly (Agricultural Statistics of Pakistan, 1980-81 to 2013-14).

\section{Yield potential}

Pakistan produces a number of oil seed crops but there is a huge gap between the potential yield and the average yield of different oilseed crops. It is noted that about 74 percent in rapeseed-mustard, 75 percent in groundnut, 72 percent in linseed, 69 percent in sunflower and 65 percent in sesame crops were unable to achieve the yield potential due to non-adaptation of proper crop management practices (Agricultural Statistics of Pakistan, 2012-13). It is a major problem that there is a big yield gap between the potential yield and the national yield, which shows that the efforts should be made to minimize the yield gap by adopting the modern technology to achieve the potential yield on account of edible oil production. The detail of yield gap of different oilseed crops is given in table-1.

\begin{tabular}{lllll}
\multicolumn{5}{c}{ Table-1 Yield gap of different oilseed crops } \\
\hline Oil seed Crops & $\begin{array}{l}\text { Potential } \\
\text { Yield }(\mathrm{kg} / \mathrm{ha})\end{array}$ & $\begin{array}{l}\text { Average Yield } \\
(\mathrm{kg} / \mathrm{ha})\end{array}$ & $\begin{array}{l}\text { Yield gap } \\
(\mathrm{kg} / \mathrm{ha})\end{array}$ & $\begin{array}{l}\text { Unachieved } \\
(\%)\end{array}$ \\
\hline Sunflower & 4,000 & 1,239 & 2,761 & 69 \\
Rapeseed-mustard & 3,500 & 922 & 2,578 & 74 \\
Groundnut & 4,000 & 995 & 3,005 & 75 \\
Sesame & 1,200 & 418 & 782 & 65 \\
Linseed & 2,500 & 710 & 1,790 & 72 \\
\hline
\end{tabular}

Source: Agricultural Statistics of Pakistan, 2012-13 


\section{Objective of the Research}

The objective of the paper is to determine that crop diversification towards production of oilseed crops reduces the import burden in Pakistan and to recommend policy prescriptions for the promotion of oilseed crops based on finding of the study.

\section{Literature Review}

Anderson and Vandervoort (1982) found that rural infrastructure development, use of agricultural credit to farmers and increased in land values were associated to the growth of agricultural production. Chand (1995), concluded that rural infrastructure played a significant role for the profitability and success of crop diversification towards the production of minor crops and it reduced the transaction costs.

De (2000) used the Herfindahl index (HI), Ogive Index (OI), Entropy Index (EI) as well as Modified Entropy Index (MEI) to check the extent of crop diversification and its variation across various districts of West Bengal and observed large scale variation in crop diversification across districts overtime were depending on the growth of utilization of improved agricultural technology.

Guvele (2001) found that crop diversification towards high value crops enhanced the income of Sudani farmers and reduced the volatility in income.

Smith, Gordon, Meadows, and Zwick (2001) concluded that infrastructure development in rural areas increased the opportunities for rural poor by accessing to product market. Estache (2003) found that infrastructure development assisted the under privilege areas to be connected with the developed markets for the transaction purpose and had access for productive activities.

Helfand and Levine (2004) observed that the efficiency measure was regressed on a set of explanatory variables which includes farm size, type of land tenure, composition of output, access to institutions and indicators of technology and input usage. The relationship between farm size and efficiency was found to be non-linear, with efficiency first falling and then rising with size. Type of land tenure, access to institutions and markets, and modern inputs were found to be important determinants of the differences in efficiency across farms.

Birthal, Joshi, Roy, and Thorat (2007) concluded that the major determinant for the growth of high value crops was urbanization and also found that infrastructure development, provision of credit to farmers and technological advancement were the other determinants that helped to boost up the production of high value crops.

Birthal et al. (2007) concluded that demand for high value crops were increased in India and farm income of farmers were also increased with the passage of time as the farmers moved from staple crops towards fruits, vegetables and oilseeds. Van den Berg et al. (2007) found that the income received from crop diversification towards high value crops in China became sustainable than the income from the rice production.

SIJMB | P-ISSN: 2313-1217 E-ISSN: 2410-1885 @ 20164 Sukkur Institute of Business Administration V.3, No.1 | Apr 16 
Rahman (2008) found that crop diversification would be a desired strategy for agricultural growth in Bangladesh and concluded that development of the rural infrastructure improved the technical efficiency and might synergistically promote crop diversification by opening up opportunities for technology diffusion, marketing, storage and resource supplies.

Ibrahim, Rahman, Envulus, and Oyewole (2009) observed that income and crop diversification was identified as basic strategy for raising income and reducing rural poverty in a rural area of North Central Nigeria based on the data collected from rural household by using the Simpson Index of Diversity (SID) and Ordinary least square (OLS) regression analysis. It was concluded that the basic determinants of crop diversification towards high value crops were the availability of tractor hiring services, high return from crop production, age and level of education of household head, number of extension visits, and availability of electricity in the household and distance from local market.

Briones (2009) concluded that evidence points to an important role for vegetables and fruits in agricultural diversification and rural development from traditional crops. He emphasized the need for the diversification that could be pro-poor as it may enhance the incomes of the smallholders and workers. It was also observed to deliver benefits to both producers and consumers from the expansion of sub-sector; vegetables and fruits output grown more rapidly than agriculture as a whole and to realize its potential for agricultural diversification and rural development policy change and institutional reforms were very important for the development of vegetables and fruits sub-sector in Philippine.

A. Abro and Sadaqat (2010) observed that income per hectare of high value crops was greater than the income per hectare of major crops in Pakistan and concluded that diversification towards high value and labor intensive crops enhanced the income as well as employment opportunities to farmers resulting into decline in poverty from rural areas. Further, A. A. Abro (2012) found that infrastructural development, increase in per capita income, and use of fertilizer and number of tube wells, availability of water for irrigation purpose, tractors, availability of credit and rainfall were the main determinants of crop diversification towards high value crops in Pakistan.

Kumar De (2013) observed that option remained for the growth of agriculture was to diversify the land use for cultivation of crops which were environment friendly and more remunerative, the choice of highly remunerative crops were also depended on the availability of appropriate infrastructure required for easy access to markets, harvest of crops on time, protection from post-harvest loses as well as proper marketing of those crops.

Ali, Erenstein, and Rahut (2014) observed that households having women's participation in farming activities were able to grow more high value crops and 
concluded that households having women's participation in farming activities have higher income and were able to keep more cattle and suggested that their participation needed to be encouraged to enhance the household income and to reduce the poverty from rural areas of Pakistan.

\section{Research Methodology}

5.1. Measurement of Crop Diversification:

The crop diversification is examined by using various indices such as, Herfindahl Index (HI), Simpson's Index (SI), Entropy Index (EI), Modified Entropy Index (MEI) and Ogive Index. The most widely indices use in agricultural diversification are the HI, SI and the entropy index, these indices are computed on the basis of share of gross cropped area under various crops cultivated.

Herfindahl Index (HI) is used to capture the change in the level of concentration and diversification in Pakistan. HI is defined as the sum of squares of ' $n$ ' proportion, this is a simple measure of concentration which shows for increasing diversification, HI is decreasing and vice versa. That is,

$$
H=\sum_{i=1}^{N} s_{i}^{2}
$$

Where $s_{i}$ represents the proportion of area under $i^{\text {th }}$ crop to Gross Cropped Area (GCA). The value of Herfindahl index lies between one and zero, it takes value one in case of perfect specialization and zero in case of perfect diversification. Lower the value of $\mathrm{HI}$ more the diversification and more the value of $\mathrm{HI}$ resulting less the diversification. We examined the share of different crops in gross cropped area during 1980-81 to 2013-14 in Pakistan, the data on area under various crops such as; food crops, cash crops, pulses, oilseeds, vegetables, condiments, fruits and others was sourced from Agricultural Statistics of Pakistan (1980-81 to 2013-14).

\subsection{Basic criteria of Herfindahl Index (HI):}

- HI below 0.01 (or 100) indicates a highly crop diversification in the country.

- HI between 0.1 (or 1,000$)$ to $0.18(1,800)$ indicates a moderate crop diversification.

- HI above $0.18(1,800)$ indicates a high level of crop concentration.

\subsection{Calculation of $\mathrm{HI}$ by using percent of crop share:}

- The Herfindahl Index is used as the square of the percentage crop share of each crop sum of squares of ' $n$ ' proportion, this is a simple measure of concentration which shows for increasing diversification, HI is decreasing and vice versa.. That is,

- $\mathrm{HI}=(\text { share of food crops })^{2}+(\text { share of Cash crops })^{2}+(\text { share of pulses })^{2}+($ share of oilseeds $)^{2}+(\text { share of vegetables })^{2}+(\text { share of condiments })^{2}+(\text { share of fruits })^{2}$ $+(\text { share of others })^{2}$

SIJMB | P-ISSN: 2313-1217 E-ISSN: 2410-1885 @ $2016 \quad 6$ Sukkur Institute of Business Administration V.3, No.1 | Apr 16 
The Herfindahl index calculated from the share of percentage of various categories of crops from 1980 to 2013 is as under;

- $\quad \mathrm{HI}(1980)=(56)^{2}+(15)^{2}+(6)^{2}+(3)^{2}+(1)^{2}+(1)^{2}+(2)^{2}+(16)^{2}$

$\mathrm{HI}(1980)=3,136+225+36+9+1+1+4+256=\mathbf{3 , 6 6 8}$

- $\quad \mathrm{HI}(1990)=(55)^{2}+(16)^{2}+(7)^{2}+(2)^{2}+(1)^{2}+(1)^{2}+(2)^{2}+(16)^{2}$

HI $(1990)=3,025+256+49+4+1+1+4+256=\mathbf{3 , 5 9 6}$

- $\quad \mathrm{HI}(2000)=(56)^{2}+(18)^{2}+(6)^{2}+(3)^{2}+(1)^{2}+(1)^{2}+(3)^{2}+(12)^{2}$

HI $(2000)=3,136+324+36+9+1+1+9+144=\mathbf{3 , 6 6 0}$

- $\quad \mathrm{HI}(2013)=(61)^{2}+(19)^{2}+(5)^{2}+(3)^{2}+(1)^{2}+(1)^{2}+(3)^{2}+(7)^{2}$

HI $(2013)=3,721+361+25+9+1+1+9+49=\mathbf{4 , 1 7 6}$

Now we compare the calculated HI of selected years (Further detail is provided at annexure-B) with the basic criteria (i.e HI above 1,800) and observed that calculated HI was greater than the basic criteria. It was found that there was a higher level of crop concentration in Pakistan and needed further crop diversification towards high value crops. (Pingali \& Rosegrant, 1995) defined diversification as "change in product (or enterprise) choice and input use decisions based on market forces and the principles of profit maximization”. Birthal et al., (2007) defined agricultural diversification as "encompasses change in production portfolio from low-value to more remunerative and high-value commodities like fruits, vegetables, oilseeds, milk, meat, eggs and fish that expand farm and non-farm sources of income". The Ordinary Least Square (OLS) technique is used to check the effects of various factors on the Index of High Value Crops (IHVC) in Pakistan by using following econometric model;

IHVC $=f$ (Import of Oilseeds, Tube wells, Domestic production of oilseeds, Credit disbursed, and Number of Tractors, $\epsilon$ )

The Index of High value Crops at constant prices with 1980 as the base year will be included as explained variable and other explanatory variables such as import of oilseeds (in 000 tons), number of tube wells (in 000), Domestic Production(in 000 tons), Credit disbursed (in billions) and number of Tractors will be used.

\section{Detail of variables and its sources}

\section{Import of oilseeds:}

Import of oilseeds (in 000 tons) is taken from the various issues of Agricultural Statistics of Pakistan.

\section{Number of Tube wells:}

The number of tube wells is taken from the various issues of the Economic Survey of Pakistan. 
Domestic production of oilseeds:

Domestic production of oilseeds (in 000 tons) is taken from the various issues of Agricultural Statistics of Pakistan.

Availability of credit:

The availability of credit for farmers is taken from the various issues of the Economic Survey of Pakistan.

\section{Number of Tractors:}

The number of tractors is taken from the various issues of the Economic Survey of Pakistan.

\section{Index of High Value Crops (IHVC):}

The Index of High Value Crops is calculated on the basis of data collected from the various issues of ESP and Agricultural Statistics of Pakistan.

\section{Factors impact the Index of High Value Crops}

To determine the impact of various factors on index of high value crops, a multiple regression analysis was used to prove that how different variables adopted in model effect the index of high value crops. The values for Index of High Value Crops were taken as explained variable and other various factors that affecting income from high value crops was included as explanatory variables. Results of the multivariate regression analysis have been presented in Table-2. The F-value was 182.25 and found overall significant. The $\mathrm{R}^{2}$ value of 0.970 meant 97.0 percent fits data extremely well. The tests of heteroscedasticity and auto-correlation were run and found that model was free from these problems.

Table 2: Determinants of Diversification towards Production of Oil seeds (1980-2013)

\begin{tabular}{lllll}
\hline \multirow{2}{*}{ Explanatory Variables } & \multicolumn{4}{l}{$\begin{array}{l}\text { Dependent Variable: Index of High value Crops } \\
\text { at 1980-81 prices }\end{array}$} \\
& Coefficient & Std. Error & $\mathrm{t}$ - value & P. Value \\
\hline Import of Oilseeds(000 tons) & -0.455484 & 0.186341 & -2.444351 & 0.0211 \\
Number of Tube wells (in 000) & 0.880132 & 0.428760 & 2.052740 & 0.0495 \\
Domestic Production(000 tons) & 1.784970 & 0.503557 & 3.544723 & 0.0014 \\
Credit disbursed (in billions) & 9.611282 & 0.895700 & 10.73047 & 0.0000 \\
Tractors & 14.92036 & 3.912370 & 3.813637 & 0.0007 \\
C & 69.10616 & 175.5598 & 0.393633 & 0.6968 \\
\hline R-squared & & & 0.970190 & \\
Adjusted R-squared & & & 0.964867 & \\
Durbin-Watson stat & & & 1.654504 & \\
F-statistic & & 182.2575 & \\
Prob(F-statistic) & & & 0.000000 & \\
\hline
\end{tabular}

SIJMB | P-ISSN: 2313-1217 E-ISSN: 2410-1885 @ 20168 Sukkur Institute of Business Administration V.3, No.1 | Apr 16 
To check the impact of import of Oilseeds on Index of High value crops; The regression coefficient of import of oilseeds showed a negative and highly significant impact which indicated that huge import of oilseeds badly effect the share of GDP contributed by the high value crops in Pakistan and also cost the public exchequer. The regression coefficient of number of tube wells showed a positive and significant influence on IHVC, it resulted that due to increase in the number of tube wells, enhanced the contribution of high value crops in GDP. The regression coefficient of local production of oilseed crops showed a positive and significant impact, it showed that increasing the area for production of oilseeds enhance the contribution of high value crops in GDP resultantly reduce the import burden. The regression coefficient of availability of credit showed a positive and significant impact on IHVC; it meant that crop diversification towards oilseeds production enhanced with the availability of credit, because farmers would be able to purchase inputs in time. The coefficient of farm machinery (tractors) showed a positive and a significant impact on Index of High Value Crops which indicated that farmers having tractors were able to diversify towards high value crops because they could perform various farming activities on time and could supply their output in market easily.

\section{Conclusion}

The OLS technique was applied to examine the impact of different factors on the IHVC in Pakistan. The regression coefficient of import of oil seeds showed a negative and highly significant impact which indicated that huge import of oil seeds badly affect the share of high value crops contributed in GDP and also cost the public exchequer. The regression coefficient of number of tube wells, availability of credit and farm machinery (tractor) showed a positive and significant impact on IHVC. The regression coefficient of local production of oilseed crops showed a positive and significant impact, it showed that increasing the area for production of oilseeds enhanced the contribution of high value crops in GDP resultantly reduce the import burden. It was also suggested that the efforts should be made to minimize the yield gap by adopting the modern technology to achieve the potential yield of oilseed crops. Farmers should be awarded with a good return in the market and country's production capacity of oilseed crops be improved by increasing local edible oil production resulting in decline in import on account of edible oil.

\section{References}

Abro, A., \& Sadaqat, M. (2010). Poverty Alleviation through diversifying towards high value crops in Pakistan. Int. J. Buss. Mgt. Eco. Res, 1(1), 1-8.

Abro, A. A. (2012). Determinants of Crop Diversification towards High Value Crops in Pakistan. Int. J. Buss. Mgt. Eco. Res, 3(3), 536-545.

Ali, A., Erenstein, O., \& Rahut, D. (2014). Gender contribution in production of high value crops: Empirical Evidence from Pakistan. JAPS, Journal of Animal and Plant Sciences, 24(3), 936-944.

SIJMB | P-ISSN: 2313-1217 E-ISSN: 2410-1885 @ 20169 Sukkur Institute of Business Administration V.3, No.1 | Apr 16 
Anderson, G. W., \& Vandervoort, C. G. (1982). Rural roads evaluation summary report.

Birthal, P. S., Joshi, P., Roy, D., \& Thorat, A. (2007). Diversification in Indian agriculture towards high-value crops: The role of smallholders: International Food Policy Research Institute (IFPRI).

Briones, R. M. (2009). Agricultural Diversification and the Fruits and Vegetables Subsector: Policy Issues and Development Constraints in the Philippines: Philippine Institute for Development Studies.

Chand, R. (1995). Agricultural Diversification and Small Farm Development in Western Himalayan Region. Paper presented at the National Workshop on Small Farm Diversification: Problems and Prospects", NCAP, New Delhi.

De, U. K. (2000). Diversification of crop in West Bengal: a spatio-temporal analysis. Artha Vijnana, 42(2), 170-182.

Estache, A. (2003). On Latin America's Infrastructure Privatization and its Distributional Effects. Available at SSRN 411942.

Guvele, C. (2001). Gains from crop diversification in the Sudan Gezira scheme. Agricultural Systems, 70(1), 319-333.

Government of Pakistan, Agricultural Statistics of Pakistan (1980-81 to 2013-14).

Government of Pakistan, Economic Survey of Pakistan (1980-81 to 2014-15). Economic Advisor's Wing, Finance Division, Islamabad.

Government of Pakistan, 50 years of Pakistan, Federal Bureau of Statistics, Statistics Division, Islamabad.

Helfand, S. M., \& Levine, E. S. (2004). Farm size and the determinants of productive efficiency in the Brazilian Center-West. Agricultural Economics, 31(2-3), 241249.

Ibrahim, H., Rahman, S., Envulus, E., \& Oyewole, S. (2009). Income and crop diversification among farming households in a rural area of north central Nigeria. Journal of Tropical Agriculture, Food, Environment and Extension, 8(2), 84-89.

Kumar De, U. (2013). Infrastructural Growth, Farm Size and Pattern of Crop Diversification across the Districts of West Bengal. Global Journal of Science Frontier Research, 13(5).

Pingali, P. L., \& Rosegrant, M. W. (1995). Agricultural commercialization and diversification: processes and policies. Food policy, 20(3), 171-185.

Rahman, S. (2008). Whether crop diversification is a desired strategy for agricultural growth in Bangladesh. Paper presented at the 82nd Annual Conference, March 31-April 2, 2008, Royal Agricultural College, Cirencester, UK.

Smith, D. R., Gordon, A., Meadows, K., \& Zwick, K. (2001). Livelihood diversification in Uganda: patterns and determinants of change across two rural districts. Food policy, 26(4), 421-435.

Van den Berg, M. M., Hengsdijk, H., Wolf, J., Van Ittersum, M. K., Guanghuo, W., \& Roetter, R. P. (2007). The impact of increasing farm size and mechanization on rural income and rice production in Zhejiang province, China. Agricultural Systems, 94(3), 841-850.

SIJMB | P-ISSN: 2313-1217 E-ISSN: 2410-1885 @ 201610 Sukkur Institute of Business Administration V.3, No.1 | Apr 16 
Annexure-A

Domestic production, import and total consumption of edible oil in Pakistan

\begin{tabular}{|c|c|c|c|c|c|}
\hline$\underline{\text { Year }}$ & $\begin{array}{l}\text { Domestic } \\
\text { production } \\
\underline{\left(' 000^{\prime} \mathrm{t}\right)}\end{array}$ & $\frac{\text { Import }}{(\text { ('000' t })^{\prime}}$ & $\begin{array}{l}\frac{\text { Total }}{\text { Consumption }} \\
\underline{\left(' 000^{\prime} t\right)}\end{array}$ & $\begin{array}{l}\text { Import as \% of } \\
\underline{\text { total consumption }}\end{array}$ & $\begin{array}{l}\text { Amount in } \\
\underline{\text { Billion }}\end{array}$ \\
\hline $1980-81$ & 247 & 465 & 712 & 65.3 & 2.61 \\
\hline $1981-82$ & 256 & 624 & 880 & 70.9 & 3.39 \\
\hline $1982-83$ & 275 & 640 & 915 & 69.9 & 3.51 \\
\hline $1983-84$ & 200 & 752 & 952 & 79.0 & 6.49 \\
\hline $1984-85$ & 309 & 653 & 962 & 67.9 & 6.78 \\
\hline $1985-86$ & 335 & 815 & 1,150 & 70.9 & 6.02 \\
\hline $1986-87$ & 334 & 687 & 1,021 & 67.3 & 3.85 \\
\hline $1987-88$ & 333 & 959 & 1,292 & 74.2 & 7.23 \\
\hline $1988-89$ & 327 & 859 & 1,186 & 72.4 & 8.41 \\
\hline $1989-90$ & 330 & 940 & 1,270 & 74.0 & 7.98 \\
\hline $1990-91$ & 338 & 960 & 1,298 & 74.0 & 9.02 \\
\hline $1991-92$ & 486 & 1,046 & 1,532 & 68.3 & 10.03 \\
\hline $1992-93$ & 348 & 1,231 & 1,579 & 78.0 & 15.19 \\
\hline 1993-94 & 317 & 1,131 & 1,448 & 78.1 & 14.69 \\
\hline 1994-95 & 344 & 1,390 & 1,734 & 80.2 & 30.78 \\
\hline $1995-96$ & 528 & 1,142 & 1,670 & 68.4 & 28.67 \\
\hline $1996-97$ & 515 & 1,057 & 1,572 & 67.2 & 23.91 \\
\hline $1997-98$ & 518 & 1,178 & 1,696 & 69.5 & 33.3 \\
\hline 1998-99 & 531 & 1,325 & 1,856 & 71.4 & 40.54 \\
\hline 1999-00 & 607 & 1,091 & 1,698 & 64.3 & 21.4 \\
\hline $2000-01$ & 642 & 1,144 & 1,786 & 64.1 & 19.04 \\
\hline 2001-02 & 497 & 1,197 & 1,694 & 70.7 & 24.03 \\
\hline 2002-03 & 475 & 1,293 & 1,768 & 73.1 & 34.29 \\
\hline 2003-04 & 494 & 1,361 & 1,855 & 73.4 & 37.91 \\
\hline 2004-05 & 583 & 1,605 & 2,188 & 73.4 & 44.98 \\
\hline $2005-06$ & 510 & 1,696 & 2,206 & 76.9 & 44.91 \\
\hline 2006-07 & 565 & 1,787 & 2,352 & 76.0 & 59.51 \\
\hline 2007-08 & 588 & 2,700 & 3,288 & 82.1 & 136.8 \\
\hline 2008-09 & 565 & 2,489 & 3,054 & 81.5 & 142.1 \\
\hline $2009-10$ & 662 & 2,238 & 2,900 & 77.2 & 148.0 \\
\hline 2010-11 & 696 & 2,383 & 3,079 & 77.4 & 224.0 \\
\hline 2011-12 & 636 & 2,148 & 2,784 & 77.2 & 216.4 \\
\hline $2012-13$ & 567 & 2,502 & 3,069 & 81.5 & 241.9 \\
\hline 2013-14 & 573 & 2,627 & 3,200 & 82.1 & 246.89 \\
\hline
\end{tabular}

Source: Agricultural Statistics of Pakistan (1980-81 to 2013-14)

SIJMB | P-ISSN: 2313-1217 E-ISSN: 2410-1885 @ 201611 Sukkur Institute of Business Administration V.3, No.1 | Apr 16 


\section{Annexure-B}

Share of Different crops in Total Cropped Area during 1980-81 to 2013-14 ('000' hectares)

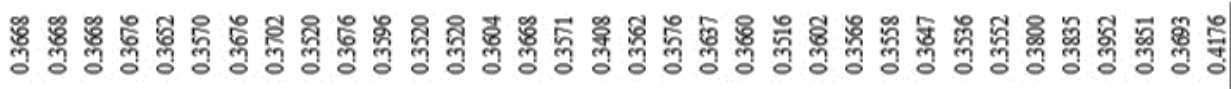

国

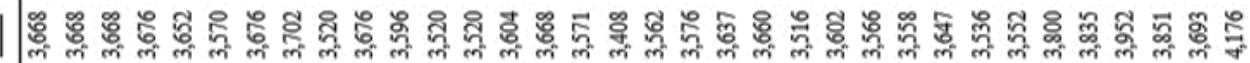

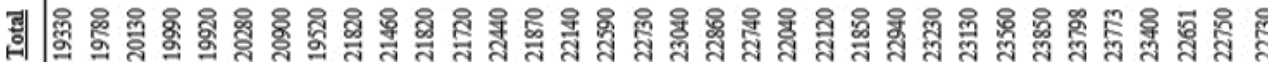

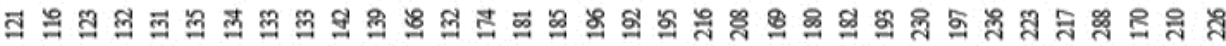

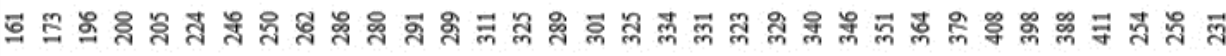

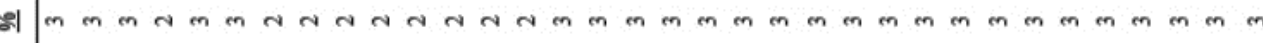

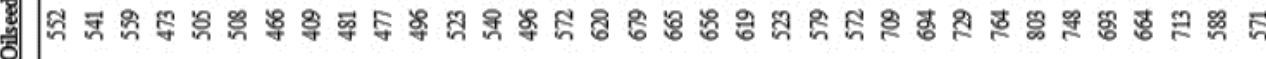
:

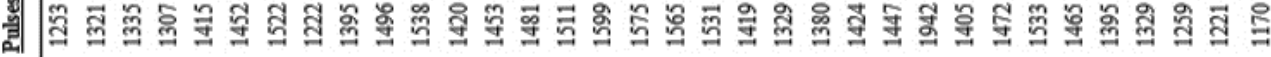

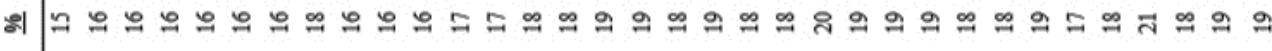

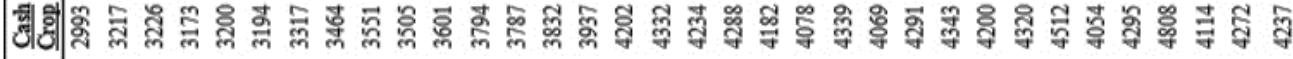

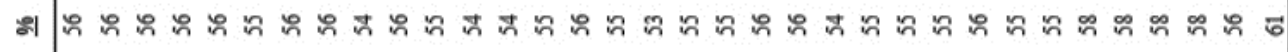

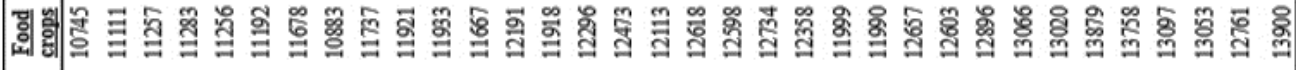

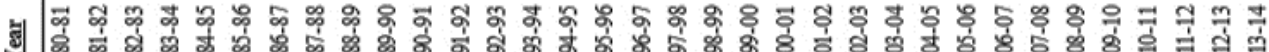
ॠ|人 